Asian Pacific Journal of Reproduction

Journal homepage: www.apjr.net

doi: $10.12980 /$ apjr.6.20170306

O2017 by the Asian Pacific Journal of Reproduction. All rights reserved.

\title{
Effect of Diospyros kaki enriched extender on cattle bull sperm parameters and conception rate
}

\author{
El-Sheshtawy RI ${ }^{\bowtie}$, El-Nattat WS \\ Animal Reproduction and AI Department., Veterinary Research Division, National Research Centre, Dokki, Egypt
}

\section{ARTICLE INFO}

Article history:

Received 16 February 2017

Revision 18 March 2017

Accepted 25 March 2017

Available online 1 May 2017

\section{Keywords:}

Cattle

Semen

Preservation

Diospyros kaki

\begin{abstract}
Objective: To explore the effect of Diospyros kaki on cattle spermatozoa during chilling and cryopreservation. Methods: Five milliliter of blended Persimmon (Diospyros kaki) flesh was added to $45 \mathrm{~mL}$ TCF to obtain $10 \%$ stock solution. Kaki enriched extender (KEE) was prepared by adding to TCF in concentrations $0.0 / 5.0 \mathrm{~mL}$ (control, $0 \%), 0.5 / 4.5 \mathrm{~mL}(1 \%), 1 / 4$ $\mathrm{mL}(2 \%), 1.5 / 3.5 \mathrm{~mL}(3 \%), 2.0 / 3.0 \mathrm{~mL}(4 \%), 2.5 / 2.5 \mathrm{~mL}(5 \%), 3.0 / 2.0 \mathrm{~mL}(6 \%), 3.5 / 1.5 \mathrm{~mL}$ (7\%), $4.0 / 1.0 \mathrm{~mL}(8 \%), 4.5 / 0.5 \mathrm{~mL}(9 \%)$ and $5.0 / 0.0 \mathrm{~mL}(10 \%)$ to obtain a final volume 5 $\mathrm{mL}$ in each tube. Whole egg yolk was added to each tube to obtain KEE with $20 \%$ egg yolk (KEEY), all tubes were centrifuged to get rid of debris. Semen was added to the supernatants in other tubes. Extended semen was subjected to evaluation [motility, alive sperm and intact sperm membrane (HOST) \%] in both chilled and cryopreserved semen. Conception rate was carried out. Results: Sperm motility was significantly $(P<0.0001)$ kept high after $11 \mathrm{~d}$ of chilling with the concentration $1 \%, 2 \%, 3 \%, 4 \%, 5 \%$ as compared to the control $(41.67 \pm 1.67$, $41.67 \pm 1.67,40.00 \pm 0.00,41.67 \pm 1.67$ and $41.67 \pm 1.67$, respectively) and also non-significantly kept high at the other concentrations up to $9 \mathrm{~d}$ of chilling. Addition of KEE had significantly $(P<0.0033)$ improved post thawing sperm motility \% with the concentrations $1,2,3,4,5$ and $6 \%$ as compared to the control $(51.67 \pm 5.27,55.00 \pm 3.16,48.33 \pm 1.05,45.00 \pm 3.96,57.00 \pm 2.50$, $55.00 \pm 5.00$ and $43.33 \pm 5.11$ respectively). While the other concentrations exhibit no effect. Addition of KEE maintained alive sperm\%, abnormalities $\%$ and $\%$ of intact spermatozoa membranes (HOST\%) as good as the control with all concentrations of kaki used in our study. The conception rate upon using frozen semen in insemination showed higher conception rate in concentrations of $2 \%, 4 \%$ and $6 \%$ KEE in cattle. Conclusion: It could be concluded that some concentrations of Diospyros kaki improved bull semen quality post-chilling and post-freezing.
\end{abstract}

\section{Introduction}

Spermatozoa are the endpoint of male spermatogenesis and have particular anatomic and metabolic features. Nowadays, Sperm cryopreservation and storage are of a great demand for conserving the supergenetic origins of the males, the development of artificial reproductive technologies such as artificial insemination (AI) and

\footnotetext{
Corresponding author: Professor Reda, I., El Sheshtawy, Animal Reproduction an Artificial Insemination Department, National Research Centre, Dokki, Giza, Egypt. Phone: 20233371635

Fax: 202-37601877

E-mail: rielsheshtawy@gmail.com
}

in vitro fertilization (IVF)[1] are of a great interest. AI with frozen semen is essential in breeding and selection schedules contributing to increase production of domestic species. Nowadays, semen cryopreservation has many biotechnological applications. It can be used to solve infertility problems, life threatening diseases,

This is an open access article distributed under the terms of the Creative Commons Attribution-Non Commercial-Share Alike 3.0 License, which allows others to remix, tweak and buid upon the work non-commercially, as long as the author is credited and the new creations are licensed under the identical terms.

For reprints contact: reprints@medknow.com

C2017 Asian Pacific Journal of Reproduction Produced by Wolters Kluwer- Medknow

How to cite this article: El-Sheshtawy RI, El-Nattat WS. Effect of Diospyros kaki enriched extender on cattle bull sperm parameters and conception rate. Asian Pac J Reprod 2017; 6(3): 128-132. 
preservation of semen and DNA from endangered species and conservation of biodiversity. The interaction of several factors (cooling rate, storage temperature, chemical ingredients of the extender, cryoprotectant concentration, over accumulation of oxygen free radicals, seminal plasma composition and hygienic control) are the key that affect the life-span of spermatozoa[2]. Cryopreservation of bovine semen often induce an additional source for reactive oxygen species (ROS) attack on sperm due to decreased activities of antioxidant enzymes and the sperm membrane become more susceptible to lipid peroxidation[3] which affect the membrane permeability[4]. Natural antioxidants exert a protective effect preserving the metabolic activity and cellular viability of cryopreserved bovine spermatozoa[5]. Nowadays, the use of herbal natural product has gained interest worldwide. Many of the herbs have been developed into herbal supplement which are claimed to assist in healthy life style. Among these herbs, is Persimmon (Diospyros kaki) fruit possessing high nutritive value and contains many biologically active substances including antioxidants, dietary fiber, triterpenoids and minerals[6-12]. Persimmons revealed considerable health and medicinal benefits, which are considered to be related to the various hydrophilic and lipophilic antioxidants including phenolic compounds, vitamin $\mathrm{C}$ and carotenoids, contained in the fruit[13]. Persimmon fruits contain abundance of nutrients and phytochemicals such as carbohydrates, organic acid, vitamins, tannins, polyphenols, dietary fiber, triterpenoids, and carotenoids, which contribute significantly to their taste, colour, nutritive and medicinal values[14-21].

No available literatures were found for interpreting the benefit for using those materials in preserving extended cattle and buffalo semen.

\section{Materials and methods}

\subsection{Preparation of semen extender}

Kaki enriched extender (KEE): $5 \mathrm{~mL}$ of blended Persimmon (Diospyros kaki) flesh was added to $45 \mathrm{~mL}$ TCF to obtain $10 \%$ stock solution. KEE was prepared by adding to TCF in concentrations $0.0 / 5.0 \mathrm{~mL}$ (control, $0 \%), 0.5 / 4.5 \mathrm{~mL}(1 \%), 1 / 4$ $\mathrm{mL}(2 \%), 1.5 / 3.5 \mathrm{~mL}(3 \%), 2.0 / 3.0 \mathrm{~mL}(4 \%), 2.5 / 2.5 \mathrm{~mL}(5 \%)$, 3.0/2.0 mL (6\%), 3.5/1.5 mL (7\%), 4.0/1.0 mL (8\%), 4.5/0.5 mL $(9 \%)$ and $5.0 / 0.0 \mathrm{~mL}(10 \%)$ to obtain a final volume $5 \mathrm{~mL}$ in each tube. Whole egg yolk was added to each tube to obtain KEE with $20 \%$ egg yolk (KEEY), all tubes were centrifuged to get rid of debris. Supernatants were transferred to other tubes and then stored at $-20{ }^{\circ} \mathrm{C}$ till used.

A preliminary study on the use of $10 \%-50 \%$ had given bad results so, the former design was introduced as the persimmon contains high amount of astringent tannin which may be the cause of those poor results.

\subsection{Semen collection and initial evaluation}

Three mature cattle bulls maintained at Semen Freezing
Center, General Organization for Veterinary Services Ministry of Agriculture, Abbasia, Egypt, were used as semen donors. Ejaculates were collected using a bovine adapted artificial vagina at weekly intervals for $18 \mathrm{wk}$. Semen samples were initially evaluated for subjective sperm motility and sperm concentration. Ejaculates fulfilling minimum standard of sperm motility $(70 \%)$ and sperm morphology pooled in order to have sufficient semen for a replicate and to eliminate the bull effect. The semen was given a holding time for $10 \mathrm{~min}$ at $37{ }^{\circ} \mathrm{C}$ in the water bath before dilution.

\subsection{Semen processing}

Semen samples were diluted with TCF extender and used as control and other aliquots of pooled semen samples were diluted with TCF extenders containing the different concentrations of kaki in order to provide concentration of 60 million sperm $/ \mathrm{mL}$. Extended semen was slowly cooled (approximately for $2 \mathrm{~h}$ ) to $5{ }^{\circ} \mathrm{C}$ and equilibrated for $2 \mathrm{~h}$. Semen was packed into $0.25 \mathrm{~mL}$ polyvinyl French straws. After equilibrium periods, the straws were horizontally placed on a rack and frozen in vapor $4 \mathrm{~cm}$ above liquid nitrogen for $10 \mathrm{~min}$ and were then dipped in liquid nitrogen. A fraction of extended semen from control and each concentration of the additives were kept at $5{ }^{\circ} \mathrm{C}$ for 7-10 d (chilling) and sperm motility was evaluated daily.

\subsection{Assessment of semen quality parameters}

The assessment was undertaken on after freeze thawing of bull spermatozoa. Also, sperm motility was evaluated for raw semen, $2 \mathrm{~h}$ after cooling and chilled semen daily up to 7-10 d. Frozen straws were thawed at $37{ }^{\circ} \mathrm{C}$ for $1 \mathrm{~min}$. The parameters studied were subjective semen characteristics (motility, alive, abnormality and hypoosmotic swelling test (HOST) \%)[22].

\subsection{Conception rate}

Conception rate no. of cows $(n=145)$ were inseminated with KEEY bull semen. Another no. of cows was inseminated with bull semen diluted with TCFY (control group). Pregnancy was confirmed by rectal palpation 2 mo later after insemination. The inseminated cows were used via the cooperation in Beni-Suef Governorate. CR was calculated according to the equation:

$$
\mathrm{CR}=\frac{\text { No. of conceived cows }}{\text { Total no. of inseminated cows }} \times 100
$$

\subsection{Statistical analysis}

Statistical analysis data were analyzed using the SPSS (2005)[23] computerized program v. 14.0 to calculate the analysis of variance 
(ANOVA) for the different parameters between control and additives replications. Significant difference between means was calculated using Duncan test at $P<0.05$.

\section{Results}

\subsection{Effect of Diospyros kaki enriched extender on cattle bull sperm motility during chilling}

Sperm motility was significantly $(P<0.0001)$ kept high after $11 \mathrm{~d}$ of chilling with the concentration $1 \%, 2 \%, 3 \%, 4 \%, 5 \%$ as compared to the control $(41.67 \pm 1.67,41.67 \pm 1.67,40.00 \pm 0.00$, $41.67 \pm 1.67$ and $41.67 \pm 1.67$, respectively) and also nonsignificantly kept high at the other concentrations up to $9 \mathrm{~d}$ of chilling (Table 1).

\subsection{Effect of Diospyros kaki enriched extender on post thawing cattle bull sperm characteristics}

Addition of KEE had significantly $(P<0.0033)$ improved post thawing sperm motility $\%$ with the concentrations $1 \%, 2 \%$, $3 \%, 4 \%, 5 \%$ and $6 \%$ as compared to the control $(51.67 \pm 5.27$, $55.00 \pm 3.16,48.33 \pm 1.05,45.00 \pm 3.96,57.00 \pm 2.50,55.00 \pm 5.00$ and $43.33 \pm 5.11$ respectively) while the other concentrations exhibit no effect. Addition of KEE maintained alive sperm\%, abnormalities\% and $\%$ of intact spermatozoa membranes (HOST \%) as good as the control with all concentrations of kaki used in our study (Table 2).

The conception rate (Table 3) upon using frozen semen in insemination showed higher conception rate in concentrations of

Table 1

Effect of Diospyros kaki enriched extender on cattle bull sperm motility during chilling.

\begin{tabular}{|c|c|c|c|c|c|c|c|c|c|c|c|c|}
\hline \multirow{2}{*}{\multicolumn{2}{|c|}{ Treatment $2 \mathrm{~h}$}} & \multicolumn{11}{|c|}{ Days } \\
\hline & & 1 & 2 & 3 & 4 & 5 & 6 & 7 & 8 & 9 & 10 & 11 \\
\hline Control & $91.67^{\mathrm{a}} \pm 1.67$ & $91.67^{\mathrm{a}} \pm 1.67$ & $86.67^{\mathrm{a}} \pm 3.33$ & $86.67^{\mathrm{a}} \pm 3.33$ & $85.00^{\mathrm{a}} \pm 2.89$ & $75.00^{\mathrm{a}} \pm 7.64$ & $71.67^{\mathrm{a}} \pm 6.01$ & $68.33^{\mathrm{a}} \pm 4.41$ & $63.33^{\mathrm{a}} \pm 3.33$ & $55.00^{\mathrm{a}} \pm 7.64$ & $45.00^{\mathrm{a}} \pm 10.41$ & $25.00 \pm 5.77$ \\
\hline 2 & $91.67^{\mathrm{a}} \pm 1.67$ & $90.00^{\mathrm{a}} \pm 0.00$ & $88.33^{\mathrm{a}} \pm 1.67$ & $86.67^{\mathrm{a}} \pm 1.67$ & $85.00^{\mathrm{a}} \pm 2.89$ & $85.00^{\mathrm{a}} \pm 5.00$ & $78.33^{\mathrm{a}} \pm 1.67$ & $71.67^{\mathrm{a}} \pm 3.33$ & $66.67^{\mathrm{a}} \pm 4.41$ & $55.00^{\mathrm{a}} \pm 5.00$ & $46.67^{\mathrm{a}} \pm 10.14$ & $41.67 \pm 1.67$ \\
\hline 3 & $91.67^{\mathrm{a}} \pm 1.67$ & $90.00^{\mathrm{a}} \pm 0.00$ & $88.33^{\mathrm{a}} \pm 1.67$ & $88.33^{\mathrm{a}} \pm 1.67$ & $86.67^{\mathrm{a}} \pm 3.33$ & $85.00^{\mathrm{a}} \pm 5.00$ & $75.00^{\mathrm{a}} \pm .00$ & $70.00^{\mathrm{a}} \pm 5.00$ & $61.67^{\mathrm{a}} \pm 7.26$ & $50.00^{\mathrm{a}} \pm 0.00$ & $41.67^{\mathrm{a}} \pm 6.01$ & $40.00 \pm 0.00$ \\
\hline 4 & $91.67^{\mathrm{a}} \pm 1.67$ & $91.67^{\mathrm{a}} \pm 1.67$ & $90.00^{\mathrm{a}} \pm 0.00$ & $90.00^{\mathrm{a}} \pm 0.00$ & $88.33^{\mathrm{a}} \pm 1.67$ & $85.00^{\mathrm{a}} \pm 2.89$ & $80.00^{\mathrm{a}} \pm 0.00$ & $76.67^{\mathrm{a}} \pm 1.67$ & $61.67^{\mathrm{a}} \pm 7.26$ & $50.00^{\mathrm{a}} \pm 0.00$ & $40.00^{\mathrm{a}} \pm 5.00$ & $41.67 \pm 1.67$ \\
\hline 5 & $91.67^{\mathrm{a}} \pm 1.67$ & $91.67^{\mathrm{a}} \pm 1.67$ & $90.00^{\mathrm{a}} \pm 0.00$ & $88.33^{\mathrm{a}} \pm 1.67$ & $86.67^{\mathrm{a}} \pm 1.67$ & $81.67^{\mathrm{a}} \pm 1.67$ & $81.67^{\mathrm{a}} \pm 1.67$ & $71.67^{\mathrm{a}} \pm 1.33$ & $56.67^{\mathrm{a}} \pm 3.33$ & $50.00^{\mathrm{a}} \pm 5.77$ & $36.67^{\mathrm{a}} \pm 8.33$ & $41.67 \pm 1.67$ \\
\hline 6 & $91.67^{\mathrm{a}} \pm 1.67$ & $91.67^{\mathrm{a}} \pm 1.67$ & $90.00^{\mathrm{a}} \pm 0.00$ & $90.00^{\mathrm{a}} \pm 0.00$ & $88.33^{\mathrm{a}} \pm 1.67$ & $85.00^{\mathrm{a}} \pm 2.89$ & $80.00^{\mathrm{a}} \pm 0.00$ & $73.33^{\mathrm{a}} \pm 1.67$ & $63.33^{\mathrm{a}} \pm 7.26$ & $55.00^{\mathrm{a}} \pm 8.66$ & $38.33^{\mathrm{a}} \pm 9.28$ & $16.67 \pm 3.33$ \\
\hline 7 & $91.67^{\mathrm{a}} \pm 1.67$ & $91.67^{\mathrm{a}} \pm 1.67$ & $88.33^{\mathrm{a}} \pm 1.67$ & $88.33^{\mathrm{a}} \pm 1.67$ & $86.67^{\mathrm{a}} \pm 3.33$ & $80.00^{\mathrm{a}} \pm 5.77$ & $75.00^{\mathrm{a}} \pm 2.89$ & $70.00^{\mathrm{a}} \pm 2.89$ & $56.67^{\mathrm{a}} \pm 9.28$ & $50.00^{\mathrm{a}} \pm 10.00$ & $36.67^{\mathrm{a}} \pm 8.82$ & $16.67 \pm 3.33$ \\
\hline 8 & $91.67^{\mathrm{a}} \pm 1.67$ & $88.33^{\mathrm{a}} \pm 1.67$ & $88.33^{\mathrm{a}} \pm 1.67$ & $88.33^{\mathrm{a}} \pm 1.67$ & $86.67^{\mathrm{a}} \pm 1.67$ & $80.00^{\mathrm{a}} \pm 5.77$ & $75.00^{\mathrm{a}} \pm 2.89$ & $68.33^{\mathrm{a}} \pm 3.33$ & $55.00^{\mathrm{a}} \pm 10.41$ & $48.33^{\mathrm{a}} \pm 10.93$ & $35.00^{\mathrm{a}} \pm 8.66$ & $16.67 \pm 3.33$ \\
\hline 9 & $91.67^{\mathrm{a}} \pm 1.67$ & $90.00^{\mathrm{a}} \pm 2.89$ & $88.33^{\mathrm{a}} \pm 1.67$ & $86.67^{\mathrm{a}} \pm 1.67$ & $86.67^{\mathrm{a}} \pm 1.67$ & $73.33^{\mathrm{a}} \pm 10.14$ & $68.33^{\mathrm{a}} \pm 7.26$ & $61.67^{\mathrm{a}} \pm 7.26$ & $55.00^{\mathrm{a}} \pm 10.41$ & $43.33^{\mathrm{a}} \pm 13.33$ & $30.00^{\mathrm{a}} \pm 13.23$ & $16.67 \pm 3.33$ \\
\hline 10 & $91.67^{\mathrm{a}} \pm 1.67$ & $88.33^{\mathrm{a}} \pm 1.67$ & $86.67^{\mathrm{a}} \pm 1.67$ & $86.67^{\mathrm{a}} \pm 1.67$ & $85.00^{\mathrm{a}} \pm 2.89$ & $71.67^{\mathrm{a}} \pm 11.67$ & $66.67^{\mathrm{a}} \pm 8.82$ & $58.33^{\mathrm{a}} \pm 10.14$ & $51.67^{\mathrm{a}} \pm 13.02$ & $40.00^{\mathrm{a}} \pm 15.28$ & $25.00^{\mathrm{a}} \pm 12.58$ & $16.67 \pm 3.33$ \\
\hline Sig. & 1.000 & 0.7314 & 0.7809 & 0.8231 & $0 . .9866$ & 0.7902 & 0.3344 & 0.3533 & 0.9401 & 0.9667 & 0.8725 & 0.0001 \\
\hline
\end{tabular}

Table 2

Effect of Diospyros kaki enriched extender on post thawing cattle bull sperm characteristics.

\begin{tabular}{llll}
\hline Treatment & Motile $(\%)$ & HOST $(\%)$ & Alive $(\%)$ \\
\hline Control & $43.33^{\mathrm{bc}} \pm 5.11$ & $81.33^{\mathrm{a}} \pm 3.33$ & $90.67^{\mathrm{a}} \pm 3.38$ \\
$1 \%$ & $51.67^{\mathrm{ab}} \pm 5.27$ & $82.33^{\mathrm{a}} \pm 2.19$ & $89.67^{\mathrm{a}} \pm 3.28$ \\
$2 \%$ & $55.00^{\mathrm{ab}} \pm 3.16$ & $88.67^{\mathrm{a}} \pm 1.67$ & $84.67^{\mathrm{a}} \pm 1.20$ \\
$3 \%$ & $48.33^{\mathrm{abc}} \pm 1.05$ & $88.00^{\mathrm{a}} \pm 2.89$ & $80.67^{\mathrm{a}} \pm 5.93$ \\
$4 \%$ & $45.00^{\mathrm{abc}} \pm 3.96$ & $86.67^{\mathrm{a}} \pm 2.33$ & $80.33^{\mathrm{a}} \pm 0.33$ \\
$5 \%$ & $57.00^{\mathrm{a}} \pm 2.50$ & $81.33^{\mathrm{a}} \pm 2.40$ & $82.33^{\mathrm{a}} \pm 1.67$ \\
$6 \%$ & $55.00^{\mathrm{ab}} \pm 5.00$ & $83.33^{\mathrm{a}} \pm 2.85$ & $82.67^{\mathrm{a}} \pm 0.33$ \\
$7 \%$ & $37.50^{\mathrm{c}} \pm 3.35$ & $88.33^{\mathrm{a}} \pm 0.67$ & 83.53 \\
$8 \%$ & $45.00^{\mathrm{bc}} \pm 2.24$ & $82.00^{\mathrm{a}} \pm 1.15$ & $83^{\mathrm{a}} \pm 3.84$ \\
$9 \%$ & $39.17^{\mathrm{c}} \pm 3.27$ & $87.00^{\mathrm{a}} \pm 4.04$ & $81.00^{\mathrm{a}} \pm 2.65$ \\
$10 \%$ & $43.33^{\mathrm{bc}} \pm 4.22$ & $85.00^{\mathrm{a}} \pm 0.58$ & $83.33^{\mathrm{a}} \pm 0.67$ \\
$F$-value & 3.12 & 1.46 & $77.67^{\mathrm{a}} \pm 0.33$ \\
$P<$ & 0.0033 & 0.2196 & $19.67^{\mathrm{a}} \pm 1.76$ \\
\hline
\end{tabular}

Duncan $P<0.05$. Different letter superscripts indicate a significant difference between means within column using the multiple range Duncan's test at $P<0.05$. 
$2 \%, 4 \%$ and $6 \% \mathrm{KEE}$ in cattle.

Table 3

Effect of Diospyros kaki enriched extender on a field conception rate test in cattle.

\begin{tabular}{ll}
\hline Treatment & Conception rate (\%) \\
\hline Control & 45.50 \\
KEE 1\% & 50.00 \\
KEE 2\% & 62.50 \\
KEE 3\% & 45.45 \\
KEE 4\% & 66.67 \\
KEE 5\% & 40.60 \\
KEE 6\% & 60.00 \\
KEE 7\% & 25.00 \\
KEE 8\% & 20.00 \\
KEE 9\% & 42.86 \\
KEE 10\% & 5.00 \\
\hline
\end{tabular}

\section{Discussion}

Cryopreservation of sperm is of a great demand[1]. According to Gadea et al.[24], Uysal and Bucak[25] and Bucak et al.[26], minimizing the physical and chemical stresses of cooling, freezing and thawing of sperm cells and consequently improving viability and subsequent fertilizing capacity is achieved by including cryoprotectants in the semen extender. Cryopreservation causes wide-ranging physical, chemical and mechanical injures to sperm membranes of all mammalian species[27], which are attributed to temperature changes, alterations in the transition from the lipid phase, production of reactive oxygen species (ROS) and osmotic stress[5,28]. Moreover, the over accumulation of ROS causes a state of oxidative stress that involves structural damage of sperm membranes, fall of intracellular ATP levels causing decreasing in the viability and motility of cryopreserved sperm[29,30]. To decrease the harmful effects of ROS, seminal plasma possesses powerful source of ROS scavengers which offer protection for equine sperm, including enzymes such as superoxide dismutase, catalase, glutathione peroxidase, and small molecular antioxidants such as ascorbic acid and $\alpha$-tocopherol [31,32].The herbal remedies contain antioxidants to counteract the deleterious action of reactive oxygen species (ROS).

The results of the present trials revealed that sperm motility of cattle semen was kept high up to $11 \mathrm{~d}$ of chilling in KEEY with the concentrations $1 \%, 2 \%, 3 \%, 4 \%$ and $5 \%$ as compared to the control. This means that semen with these concentrations could be used in AI up to $11 \mathrm{~d}$ of chilling. Also, with the other concentrations of KEEY semen could be used in AI up to $9 \mathrm{~d}$ of chilling. On the other hand, KEEY significantly improved post thawing sperm motility with the concentrations $1 \%, 2 \%, 3 \%, 4 \%, 5 \%$ and $6 \%$ and also maintained alive sperm $\%$, abnormalities and $\%$ of intact spermatozoa membranes. Conversely, KEEY had improved the post thawing sperm motility with all concentrations (1\%-9\%) except the $10 \%$. All the used concentrations (1\%-10\%) had maintained alive $\%$, Abnormalities $\%$ and $\%$ of intact spermatozoa membranes (HOST \%). Higher conception rate in cattle with concentrations $2 \%$ and $4 \%$ kaki $(62.50 \%$ and $66.67 \%$ respectively) coincide with the good post-thawing sperm parameters with these concentrations (sperm motility 55.00 \pm 3.16 and $45.00 \pm 3.96$ respectively, Host $88.67 \pm 1.67$ and $86.67 \pm 2.33$ respectively, alive $84.67 \pm 1.20$ and $80.33 \pm 0.33$ respectively, abnormalities $17.33 \pm 0.58$ and $8.67 \pm 1.76$, respectively). Higher conception rate with the $6 \%$ kaki concentration $(60.00 \%)$ come in accordance with the higher post thawing sperm parameters with this concentration (sperm motility 55.00 \pm 5.00 , Host $83.33 \pm 2.85$, alive $82.67 \pm 0.33$ and abnormalities $16.33 \pm 3.84$ ).

Cryopreservation of bovine semen often exert an additional source of reactive oxygen (ROS) attack and lipid peroxidation[3] which affects the membrane permeability[4]. The increased ROS level is due to the decreased activities of antioxidant enzymes. Natural antioxidants protect and preserve the metabolic activity and cellular viability of cryopreserved bovine spermatozoa[5]. Diospyros kaki is rich in strong antioxidants as represented by high contents of carotenoids[11,33], flavonoids and polyphenols[34-36], organic acids and vitamins[11,37], carbohydrates[11,38] and minerals[39]. Olayemi et al.[40] and Aljady et al.[41] recorded that phenolic acids and flavonoids have strong antioxidant capacity and improved semen quality of preserved semen. Flavonoids are excellent scavengers of free radicals and the number of hydroxyl group on the phenyl ring enhances the antioxidant capacity of polyphenolic molecule[42,43]. Kaki is rich in flavonoids which have strong antioxidants activity and suppressing the production of malondialdehyde and nitric oxide and inhibit apoptosis[35]. El-Sheshtawy et al.[44, 45] conclude that pollen grains and honey improved preservability of bull semen due to its high contents of antioxidants flavonoids, vitamins and organic acids. It could be concluded that natural additives to semen extenders (moringa, kaki and silymarin) improved semen preservability in both chilled and frozen semen.

\section{Conflict of interest statement}

The authors hereby certify that they have no conflict of interest.

\section{References}

[1] Medeiros CM, Forell F, Oliveira AT, Rodrigues JL. Current status of sperm cryopreservation: Why isn't better. Theriogenology 2002; 57(1): 327-344.

[2] Barbas JP, Mascarenhas RD. Cryopreservation of domestic animal sperm cells. Cell Tissue Bank 2009; 10(1): 49-62.

[3] El-Sisy GA, El-Nattat WS, El-Sheshtawy RI. Buffalo semen quality, antioxidants andperoxidation during chilling and cryopreservation. Online J Vet Res 2007; 11: 55-61.

[4] Awda BJ, Mackenzie-Bell M, Buhr MM. Reactive oxygen species and boar sperm function. Biol Reprod 2009; 81(3): 553-561.

[5] Câmara DR, Mello-Pinto MMC, Pinto IC, Brasil OO, Nunes JF, Guerr MMP. Effects of reduced glutathione and catalase on the kinematics and membrane functionality of sperm during liquid storage of ram semen. Small Rumin Res 2011; 100(1): 44-49.

[6] Gorinstein S, Zemser M, Zachwieja Z, Weisz M, Folta M, Barton H, et al. Comparative contents of dietary fiber, total phenolics, and minerals in persimmons and apples. J Agric Food Chem 2001; 49(2): 952-957. 
[7] Chen XN, Fan JF, Yue X, Wu XR, Li LT. Radical scavenging activity and phenolic compounds in persimmon (Diospyros kaki L. cv. Mopan). J Food Sci 2008; 73(1): C24-C28.

[8] Park Y-S, Leontowicz H, Leontowicz M, Namiesnik J, Jesion I, Gorinstein. Nutraceutical value of persimmon (Diospyros kaki Thunb) and its influence on some indices of atherosclerosis in an experiment on rats fed cholesterol containing diet. Adv Hort Sci 2008; 22(4): 250-254.

[9] Akter MS, Eun JB. Characterization of insoluble fibers prepared from the peel of ripe soft persimmon (Diospyros kaki L. cv. Daebong). Food Sci Biotechnol 2009; 18: 1545-1547.

[10]Veberic R, Jurhar J, Mikulic-Petkovsek M, Stampar F, Schmitzer V. Comparative study of primary and secondary metabolites in 11 cultivars of persimmon fruit (Diospyros kaki L.). Food Chem 2010; 119(2): 477483.

[11]Zhou C, Sheng Y, Zhao D, Wang Z, Tao J. Variation of oleanolic and ursolic acid in the flesh of persimmon fruit among different cultivars. Molecules 2010; 15(9): 6580-6587.

[12]Dembitsky VM, Poovarodom S, Leontowicz H, Leontowicz M, Trakhtenberg S, Gorinstein S, et al. The multiple nutrition properties of some exotic fruits: Biological activity and active metabolites. Food Res Int 2011; 44(7): 1671-1701.

[13]George AP, Redpath S. Health and medicinal benefits of persimmon fruit: A review. Adv Hort Sci 2008; 22(4): 244-249.

[14]Celik A, Ercisli S. Persimmon cv. Hachiya (Diospyros kaki Thunb.) fruit: Some physical, chemical and nutritional properties. Int J Food Sci Nutr 2008; 59(7-8): 599-606.

[15]Del Bubba M, Giordani E, Pippucci L, Cincinelli A, Checchini L, Galvan P. Changes in tannins, ascorbic acid and sugar contents in astringent persimmons during on-tree growth and ripening and in response to different postharvest treatments. J Food Compos Anal 2009; 22(7-8): 668677.

[16]Ebert G, Gross J. Carotenoid changes in the peel of ripening persimmon (Diospyros kaki) cv Triumph. Phytochemistry 1985; 24(1): 29-32.

[17]Gorinstein S. Comparative content of total polyphenols and dietary fiber in tropical fruits and persimmon. J Nutr Biochem 1999; 10(6): 367-371.

[18]Liu YJ, Xie JL. Ursolate compounds from fruit of Diospyros kaki L. f. (in Chinese). J Plant Resour Environ 2001; 10: 1-3.

[19]Ma Q, Qin T, Zhang Q. Analysis of ingredient in persimmon frost (in Chinese). Food Res Dev 2005; 26: 143-145.

[20]Matsuo T, Ito $\mathrm{S}$. The chemical structure of Kaki-tannin from immature fruit of the persimmon (Diospyros kaki L.) (in Japanese). Agr Biol Chem 1978; 42: 1637-1643.

[21]Yuan B, Xu HL, Leng SP. Content and chemical composition of carotenoids in persimmon fruit (in Chinese). Chin Agr Sci Bull 2006; 22: 277-280.

[22]Salisbury GW, Van Demark NL, Lodge JR. Semen evaluation: In "Physiology of Reproduction and Artificial Insemination of Cattle." 2nd ed. Sanfrancisco: W.H. Freeman \& Compagny; 1978. pp. 400-427.

[23]SPSS. SPSS v.14.0 for Windows Evaluation Version Release. 14.0.0. 2005.

[24]Gadea J, Gumbo D, Novass C, Zquezf AZ, Grullol A, Gardo GC. Supplementation of the dilution medium after thawing with reduced glutathione improves function and the in vitro fertilizing ability of frozenthawed bull spermatozoa. Int J Androl 200; 31(1): 40-49.

[25]Uysal O, Bucak MN. Effects of oxidized glutathione, bovine serum albumin, cysteine and lycopene on the quality of frozen-thawed ram semen. Acta Vet Brno 2007; 76: 383-390.

[26]Bucak MN, Atessahin A, Yuce A. Effect of anti-oxidants and oxidative stressparameters on ram semen after the freeze-thawing process. Small
Rum Res 2008; 75(2-3): 128-134.

[27]Watson PF. The causes of reduced fertility with cryopreserved semen Anim Reprod Sci 2000; 60-61: 481-492.

[28]Ortega Ferrusola C, González Fernández L, Morrell JM, Salazar Sandoval C, Macías García B, Rodríguez-Martinez H, et al. Lipid peroxidation, assessed with BODIPY-C11, increases after cryopreservation of stallion spermatozoa, is stallion dependent and is related to apoptotic-like changes. Reproduction 2009; 138(1): 55-63

[29]Baumber J, Ball BA, Gravence CG, Medina V, Davies-Morel MC. The effect of reactive oxygen species on equine sperm motility, viability, acrosomal integrity, mitochondrial membrane potential, and membrane lipid peroxidation. J Androl 2000; 21(6): 895-902.

[30]Agarwal A, Prahakaran SA, Said TM. Prevention of oxidative stress injury to sperm. J Androl 2005; 26(6): 654-660.

[31]Aitken RJ, Baker MA. Oxidative stress and male reproductive biology. Reprod Fertil Dev 2004; 16(5): 581-588.

[32]Sikka SC. Role of oxidative stress and antioxidants in andrology and assisted reproductive technology. J Androl 2004; 25(1): 5-18.

[33]Zaghdoudi K, Pontvianne S, Framboisier X, Achard M, Kudaibergenova $\mathrm{R}$, Trabelsi MA, et al. Accelerated solvent extraction of carotenoids from: Tunisian Kaki (Diospyros kaki L.), peach (Prunus persica L.) and apricot (Prunus armeniaca L.). Food Chem 2015; 184: 131-139.

[34]Denev P, Yordanov A. Total polyphenol, proanthocyanidin and flavonoid content, carbohydrate composition and antioxidant activity of persimmon (Diospyros kaki L.) fruit in relation to cultivar and maturity stage. Bulg $J$ Agric Sci 2013; 19(5): 981-988.

[35]Sun L, Zhang J, Fang K, Ding Y, Zhang L, Zhang Y. Flavonoids from persimmon (Diospyros kaki) leaves (FPL) attenuate $\mathrm{H}_{2} \mathrm{O}_{2}$-induced apoptosis in MC3T3-E1 cells via the NF- K B-pathway. Food Funct 2014; 5(3): 471-479.

[36]Xie C, Xie Z, Xu X, Yang D. Persimmon (Diospyros kaki L.) leaves: A review on traditional uses, phytochemistry and pharmacological properties. J Ethnopharmacol 2015; 163: 229-240.

[37]Karakasova L, Babanovska-Milenkovska F, Lazov M, Karakasov B, Stojanova M. Quality properties of solar dried persimmon (Diospyros kaki). J Hygienic Eng Design 2013; 4: 54-59.

[38]Baltacioglu H, Artik N. Study of postharvest changes in the chemical composition of persimmon by HPLC. Turk J Agric For 2013; 37(5): 568574.

[39]Marqués AM, Domingo A, Cervera ML, de la Guardia M. Mineral profile of kaki fruits (Diospyros kaki L.). Food Chem 2015; 172: 291-297.

[40]Olayemi F, Adedayo R, Muhummad R, Bamishaiye E. The nutritional quality of three varieties of zobo (Hibiscus sabadariffa) subjected to the same preparation condition. Plant Food Hum Nutr 2011; 6: 10-15.

[41]Aljady AM, Kamaruddin MY, Jamal AM, Mohd Yassin MY. Biochemical study on the efficacy of Malaysian honey in infected wounds: An animal model. Med J Islam Acad Sci 2000; 13(3): 125-132.

[42]Wettasinghe M, Shahidi. Scavenging of reactive-oxygen species and DPPH free radicals by extracts of borage and evening primrose meals. Food Chem 2000; 70: 17-26.

[43]LeBlanc BW, Davis OK, Boue S, DeLucca A, Deeby T. Antioxidant activity of Sonoran Desert bee pollen. Food Chem 2009; 115(4): 1299 1305 .

[44]El-Sheshtawy RI, El-Nattat WS, Ali AH, Sabra HA. The Effect of Phoenix dactylifera pollen grains tris-infusion on semen preservability of local bull breeds. Glob Vet 2014; 13(5): 728-732.

[45]El-Sheshtawy RI, El-Nattat WS, Sabra HA, Ali AH. Effect of honey solution on semen preservability of local breeds of cattle bulls. Wld Appl Sci J 2014; 32(10): 2076-2078. 